\title{
Pendapatan Orang Tua Terhadap Prestasi Akademik Mahasiswa Sastra Arab Universitas Al-Azhar Indonesia
}

\author{
Zaqiatul Mardiah, S.S., M.Hum*, Yogo Purwono, M.M, FRM. \\ Fakultas Sastra, Universitas Al-Azhar Indonesia, Jl. Sisingamangaraja, Jakarta 12110 \\ Tel. 021-7244456, fax. 7244767, \\ *Penulis unutk korespondensi : zaqiah@uai.ac.id
}

\begin{abstract}
Abstraksi - Penelitian ini secara umum bertujuan memperoleh fakta empiris tentang pendapatan keluarga dan kaitannya dengan prestasi akademik mahasiswa, khususnya pada mahasiswa sastra Arab UAI. Prestasi akademik merujuk pada indeks prestasi kumulatif per semester atau pertahun. Secara teoritis prestasi akademik dipandang sebagai output dari koleksi investasi dalam pendidikan. Namun, Meskipun prestasi akademik siswa dianggap sebagai output langsung dari input alokasi investasi dalam pendidikan yang diusahakan oleh orang tua, tingkat keberhasilannya dianggap bergantung pada sejumlah faktor eksogen yang melekat pada siswa, keluarga, atau sekolah. Faktor-faktor eksogen ini antara lain adalah kumpulan karakteristik anak atau siswa, seperti jenis kelamin, usia dan kemampuan bawaan. Dengan menggunakan analisa deskriptif dan analisa inference, diperoleh hasil penelitian yang menyatakan bahwa prestasi akademik mahasiswa menurut kelompok pendapatan orang tua, tidak bisa terlihat secara nyata, pada masing-masing tahun masuk atau angkatan di UAI. Hal yang sama juga ditemukan pada analisa perbedaan prestasi akademik mahasiswa menurut kelompok pendapatan orang tua, pada masingmasing kelompok jenis kelamin, status beasiswa, dan pendidikan terakhir sebelum memasuki UAI. Ini menunjukkan bahwa karakteristik siswa belum cukup kuat untuk mendukung kita membedakan perbedaan prestasi akademik mahasiswa berdasarkan pendapatan orang tua mereka.
\end{abstract}

Kata kunci - Pendapatan orang tua, IPK, Faktor Eksogen, Hasil Estimasi Regresi, Analisa deskriptif dan Analisa Inference.
Abstract - The aim of this reseach is to empirically investigate the relation between academic achievement and parent's income of students in the department of arabic at the University of Al-Azhar Indonesia. The arabic department students that has been admitted to the University from 2008 to 2011 academic year are selected to be a sample in this study. Using the student's first year grade point average (GPA), as the proxy of student's academic achievement, and his/her ordinal scaled monthly parent's income as independent variable, as well as other student's characteristic variables as additional exogenous variables, the study reveals that the arabic students academic achievement are on average not signficantly different based on their parent's income, especially for those students with motnhly parents equals to or gretaer than ten million rupiahs (high income level). For those wiht parents income less than ten million rupiahs, there is slightly the negative relation between students academic achievement and their parents income, but the result of testing hypothesis do not support this descriptive statistics. Similar results are found when student's chracteristics such as gender, admission year into the University, and the type of pre-university eduacation, are included in the analysis. There is no significantly differences in general in academic achievement between students in different parents income level. However if we group students based on their characteristics, there are some differences significantly found in the academic achievement of students in different particular characteristic, especially in different entry academic year, gender or the type of their last education. 
Keywords : Parent's income, academic achievement, exogenous characteristics, descriptive analisys, and analysis of variance.

\section{PENDAHULUAN}

Program Studi (prodi) Arab UAI merupakan salah satu prodi yang berada di bawah fakultas sastra UAI. Jumlah siswa yang diterima di prodi Arab menempati urutan ketiga terbanyak setelah prodi Inggris dan Jepang. Umumnya siswa-siswa di prodi Arab berasal dari keluarga dengan strata sosial menengah ke bawah. Ada juga beberapa siswa yang berasal dari keluarga dengan strata sosial yang tinggi, namun ini kasus yang jarang dan tidak selalu ada di setiap angkatan. Oleh karena itu, tidak mengherankan, jika rata-rata siswa di prodi Arab berusaha mencari bantuan finansial dari berbagai sumber untuk mendanai studi mereka.

Dengan keragaman latar belakang keluarga, latar belakang pendidikan pra universitas dan jenis mata kuliah yang harus dihadapi, sangat menarik untuk dipelajari bagaimana interaksi atau keterkaitan antara prestasi akademik dan pendapatan keluarga dari mahasiswa-mahasiswa prodi Arab di UAI. Selain itu, sangat menarik juga mengelaborasi lebih jauh bagaimana dampak pendapatan keluarga pada prestasi akademik mahasiswa dapat berbedabeda pada beragam karakteristik mahasiswa.

Secara umum, penelitian ini bertujuan :

1. Mengevaluasi adakah perbedaan dalam prestasi akademik mahasiswa sastra arab UAI selama tahun pertama perkuliahan mereka, berdasarkan perbedaan level pendapatan orang tua mereka.

2. Mengevaluasi apakah karakteristik mahasiswa seperti jenis kelamin, tahun masuk, latar belakang pendidikan terakhir, dan status pembiayaan kuliah, menjelaskan pola persebaran prestasi akademik yang berbeda, berdasarkan perbedaan level pendapatan orang tua mereka.

\section{LANDASAN TEORI}

Dalam sejumlah penelitian, prestasi akademik dapat dipandang dalam perspektif fungsi produksi pada studi ekonomi. Prestasi akademik siswa dipandang sebagai output dari koleksi investasi dalam pendidikan, seperti lama tahun bersekolah dan input pendidikan yang lain, seperti pengeluaran untuk buku teks, bahan bacaan tambahan dan layanan tutorial. Meskipun prestasi akademik siswa dianggap sebagai output langsung dari input alokasi investasi dalam pendidikan yang diusahakan oleh orang tua, tingkat keberhasilannya dianggap bergantung pada sejumlah faktor eksogen yang melekat pada siswa, keluarga, atau sekolah. Faktor-faktor eksogen ini antara lain adalah kumpulan karakteristik anak atau siswa, seperti jenis kelamin, usia dan kemampuan bawaan. Dalam terminologi matematis, fungsi produksi prestasi akademik dapat diekspresikan sebagai berikut:

$$
\mathrm{H}=\mathrm{Hp}(\mathbf{E} ; \mathbf{s}, \mathbf{f}, \mathbf{q})
$$

H mewakili kemampuan akademik siswa, $\mathbf{E}$ adalah koleksi investasi dalam pendidikan, $\mathbf{s}$ adalah vektor karakteristik siswa, f adalah himpunan karakteristik latar belakang keluarga, dan q himpunan kualitas sekolah. Jika semua peubah yang termasuk dalam $\mathrm{E}, \mathrm{s}, \mathrm{f}$, dan q dapat teramati dan tersedia, persamaan (1) dapat ditaksir dengan mudah, dengan menggunakan metode kuadrat terkecil sederhana (OLS). Namun, di dalam praktik, tidak semua jenis survei dapat mengoleksi informasi tentang semua peubah itu, sehingga selalu terdapat kemungkinan adanya bias dari peubah-peubah yang tidak dipertimbangkan itu. Untuk mengatasi masalah ini, kita dapat pandang problem prestasi akademik siswa dari perspektif fungsi permintaan. Dalam hal ini, setiap rumah tangga dipandang akan memaksimumkan fungsi utilitas (quasi-concave) dari mengonsumsi kebutuhan rumah tangga $\mathrm{C}$ dan mendanai anak untuk mencapai prestasi akademik $\mathrm{H}$ :

$$
\text { Maks } \mathrm{U}=\mathrm{U}(\mathrm{C}, \mathrm{H})
$$

Dalam proses maksimalisasi utilitas ini, rumah tangga dihadapkan pada dua kendala yaitu kendala anggaran dan kendala teknologi. Total sumber daya moneter $M$ yang dimiliki rumah tangga dianggap terbatas dan anggaran untuk membeli kebutuhan rumah tangga $\mathrm{C}$ dan membiayai investasi pendidikan $\mathrm{E}$ dianggap hanya berasal dari anggaran yang terbatas itu. Kendala teknologi diwakili oleh persamaan (1). Dalam situasi seperti ini, terciptalah permintaan terhadap konsumsi rumah tangga $\mathrm{C}$ dan investasi pada elemen pendidikan Ej sebagai berikut : 


$$
\begin{aligned}
& C=C(p, M ; s, f, q) \\
& C=C(p, M ; s, f, q) \\
& E j=E j(p, M ; s, f, q)
\end{aligned}
$$

Dengan demikian, problem maksimalisasi utilitas identik dengan memenuhi permintaan terhadap prestasi anak atau siswa dengan bentuk fungsional sebagai berikut :

$$
\mathrm{H}=\mathrm{HD}(\mathrm{p}, \mathrm{M} ; \mathrm{s}, \mathrm{f}, \mathrm{q})
$$

Kuantitas permintaan terhadap prestasi anak dalam persamaan (5) adalah persamaan permintaan dalam bentuk reduced-form (ini merupakan lawan dari bentuk struktural pada persamaan (1)). Fungsi permintaan reduced-form lebih menarik untuk dimanfaatkan dalam analisa, karena paling tidak untuk dua alasan. Pertama, hubungan dalam bentuk reduced-form mempertimbangkan penyesuaian perilaku (melalui proses optimalisasi) terhadap pengeluaran dana untuk pendidikan $\mathrm{E}$ sebagai respon terhadap perubahan eksogen dari suatu peubah eksogen ( $p, M$; s, f, q), dengan mempertahankan hal-hal yang lain tidak berubah. Sejauh bahwa program-program intervensi pemerintah akan menyebabkan terjadinya penyesuaian perilaku, fungsi permintaan di (5) mungkin paling relevan bagi pengambil kebijakan (Blau, 1999). Kedua, persyaratan data untuk menduga fungsi permintaan reduced-form lebih mudah untuk dicari atau diusahakan, dibandingkan untuk menduga model struktural. Karena semua input $\mathrm{E}$ telah disubstitusi $\mathrm{p}$ dan $\mathrm{M}$, maka hasilhasil pendugaan, kecil kemungkinannya untuk megalami bias dalam peubah-peubah yang diabaikan.

\section{METODE DAN MATERIAL}

Objek penelitian ini adalah mahasiswa-mahasiswa program sarjana di prodi Arab UAI yang terdaftar pada angkatan 2008 hingga 2011. Para mahasiswa dikelompokkan ke dalam tiga kelompok atau strata berdasarkan tingkat pendapatan orang tua mereka, rendah, menengah dan tinggi. Para mahasiswa juga dikelompokkan berdasarkan tahun masuk mereka. Prestasi akademik diukur dari IPK mereka pada tahun pertama perkuliahan.

Data tentang tahun masuk, jenis kelamin, pendidikan terakhir sebelum universitas, jenis pembiayaan kuliah, IPK tahun pertama, dan pendapatan orang tua, dikumpulkan dari 79 mahasiswa yang dipilih secara acak dari empat angkatan, dengan cara menjawab kuesioner.

Penelitian ini bertujuan untuk menjawab pertanyaan-pertanyaan riset sebagai berikut:

(1) Adakah perbedaan dalam kemampuan akademik pada tahun pertama perkuliahan, di antara mahasiswa-mahasiswa yang berasal dari latar belakang ekonomi orang tua yang berbeda-beda?

(2) Adakah perbedaan dalam kemampuan akademik pada tahun pertama perkuliahan, di antara mahasiswa-mahasiswa yang berasal dari latar belakang ekonomi orang tua yang berbeda, pada kelompok mahasiswa dengan jenis kelamin tertentu?

(3) Adakah perbedaan dalam kemampuan akademik pada tahun pertama perkuliahan, di antara mahasiswa-mahasiswa yang berasal dari latar belakang ekonomi orang tua yang berbeda, pada kelompok mahasiswa dengan tahun masuk tertentu?

(4) Adakah perbedaan dalam kemampuan akademik pada tahun pertama perkuliahan, di antara mahasiswa-mahasiswa yang berasal dari latar belakang ekonomi orang tua yang berbeda, pada kelompok mahasiswa dengan latar belakang pendidikan pra-universitas (lulusan SMA, SMK, Aliyah, atau Pondok Pesantren) tertentu?

(5) Adakah perbedaan dalam kemampuan akademik pada tahun pertama perkuliahan, di antara mahasiswa-mahasiswa yang berasal dari latar belakang ekonomi orang tua yang berbeda, pada kelompok mahasiswa dengan status pembiayaan kuliah (mengandalkan beasiswa atau bukan beasiswa) tertentu?

Untuk menjawab pertanyaan-pertanyaan riset di atas, kami akan uji hipotesa nol-hipotesa nol sebagai berikut :

$\mathrm{H}_{01}$ : Tidak ada perbedaan dalam kemampuan akademik pada tahun pertama perkuliahan, diantara mahasiswa-mahasiswa yang berasal dari latar belakang ekonomi orang tua yang berbedabeda.

$\mathrm{H}_{02}$ : Tidak ada perbedaan dalam kemampuan akademik pada tahun pertama perkuliahan, diantara mahasiswa-mahasiswa yang berasal dari latar belakang ekonomi orang tua yang berbeda, pada kelompok mahasiswa dengan jenis kelamin tertentu. 
$\mathrm{H}_{03}$ : Tidak ada perbedaan dalam kemampuan akademik pada tahun pertama perkuliahan, diantara mahasiswa-mahasiswa yang berasal dari

\section{Tabel 1a. Descriptive statistic pendapatan bulanan orang tua mahasiswa prodi Arab UAI menurut tahun masuk (angkatan).}

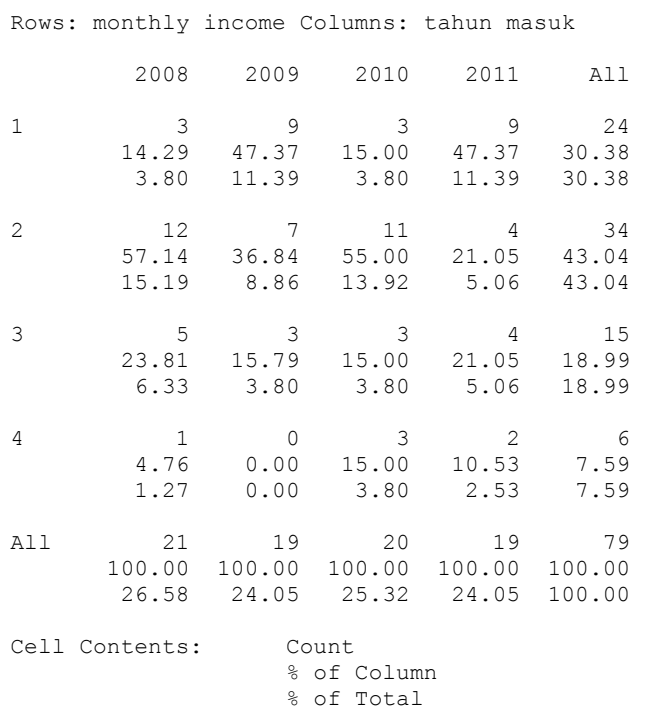

latar belakang ekonomi orang tua yang berbeda, pada kelompok mahasiswa dengan tahun masuk tertentu.

$\mathrm{H}_{04}$ : Tidak ada perbedaan dalam kemampuan akademik pada tahun pertama perkuliahan, diantara mahasiswa-mahasiswa yang berasal dari latar belakang ekonomi orang tua yang berbeda, pada kelompok mahasiswa dengan latar belakang pendidikan pra-universitas (lulusan SMA, SMK, Aliyah, atau Pondok Pesantren) tertentu?

$\mathrm{H}_{05}$ : Tidak ada perbedaan dalam kemampuan akademik pada tahun pertama perkuliahan, diantara mahasiswa-mahasiswa yang berasal dari latar belakang ekonomi orang tua yang berbeda, pada kelompok mahasiswa dengan status pembiayaan kuliah (mengandalkan beasiswa atau bukan beasiswa) tertentu.

Analisa dilakukan dalam dua tahap. Pertama, analisa deskriptif dan kedua, analisa inference. Analisa deskriptif dilakukan untuk memperoleh gambaran umum dari karakteristik sampel yang diteliti.

Analisa inferens dilakukan untuk mengevaluasi apakah dugaan-dugaan tentang keragaman prestasi akademik dan pendapatan orang tua, memperoleh dukungan empiris dari pengujian-pengujian statistik tertentu. Pengujian statistik untuk memperoleh jawaban dari hipotesa pertama, akan digunakan analysis of variance (ANOVA) satu arah dan analisa regresi linier sederhana dengan variabel tak bebas IPK tahun pertama dan variabel bebas dummy variabel tentang level pendapatan orang tua. Pengujian statistik untuk memperoleh jawaban dari hipotesa kedua sampai hipotesa kelima, masing-masing akan digunakan analisa berdasarkan generalized linear model, dengan variabel respon adalah IPK tahun pertama dan variabel penjelasnya adalah level pendapatan orang tua, karakteristik mahasiswa, dan interaksi antara level pendapatan orang tua dan masingmasing karakteristik mahasiswa.

\section{HASIL PENAKSIRAN DAN PEMBAHASAN}

\subsection{Pola Persebaran Pendapatan Orang Tua}

Tabel 1a, 1b, 1c, dan 1d, menyajikan statistik deskriptif data sampel mahasiswa prodi Arab UAI yang digunakan sebagai objek penelitian. Pendapatan bulanan orang tua dikelompokkan ke dalam empat kategori dengan menggunakan skor kategori berskala ordinal dengan pengertian sebagai berikut:

- 1 jika pendapatan orang tua kurang dari 2 juta rupiah.

- 2 jika pendapatan orang tua 2 juta rupiah hingga kurang dari 5 juta rupiah.

- 3 jika pendapatan orang tua 5 juta rupiah hingga kurang dari 10 juta rupiah, dan

- 4 jika pendapatan orang tua 10 juta rupiah dan selebihnya

Tabel 1a (di samping) menjelaskan bahwa secara umum, proporsi mahasiswa yang dijadikan sampel dari masing-masing angkatan relatif berimbang, yaitu antara 24 hingga 27 persen. Proporsi terbesar berasal dari angkatan 2008 dengan jumlah unit sampel sebanyak 21 mahasiswa atau sekitar 26,50 persen. Dari empat angkatan, mahasiswa angkatan 2009 dan 2011, adalah sampel yang proporsi paling rendah, yaitu sekitar 24 persen.

Tabel $1 \mathrm{~b}$ menyajikan pendapatan orang tua mahasiswa menurut jenis kelamin mahasiwa. Mahasiswa dengan skor 1 adalah mahasiswa perempuan, sedangkan mahasiswa dengan skor 2 adalah mahasiswa berjenis kelamin laki-laki. 
Secara umum, mahasiswa perempuan mengambil porsi terbesar dari sampel. Mereka mewakili 56 persen dari seluruh unit sampel mahasiswa. Sedangkan mahasiswa laki-laki hanya mewakili 44 persen dari seluruh unit sampel mahasiswa.

Tabel 1b. Descriptive statistic pendapatan bulanan orang tua mahasiswa prodi Arab UAI menurut jenis kelamin.

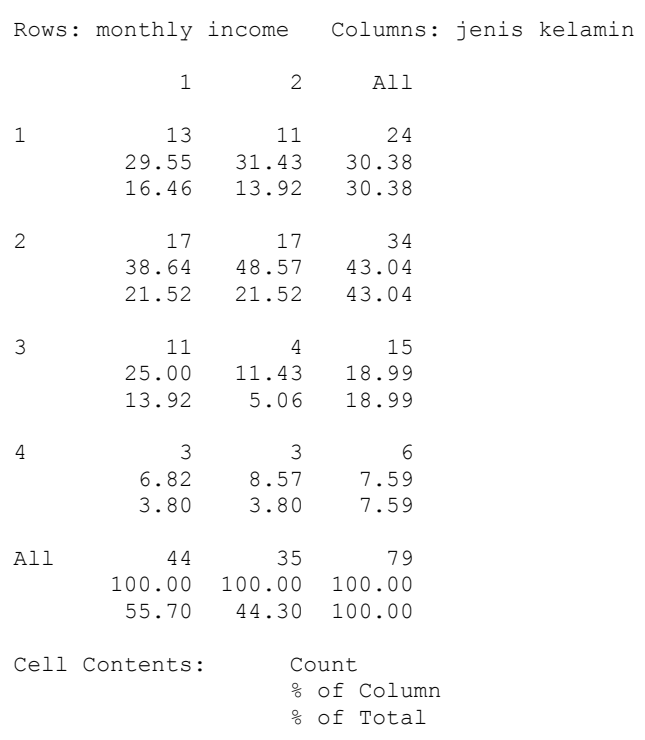

Tabel 1c. Descriptive statistic pendapatan bulanan orang tua mahasiswa prodi Arab UAI menurut pendidikan pra-UAI.

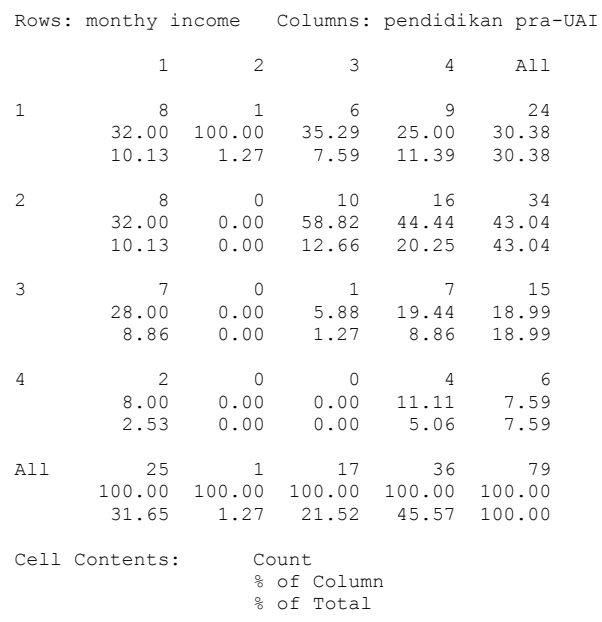

Tabel 1c menjelaskan pendapatan orang tua mahasiswa menurut pendidikan terakhir mereka sebelum masuk di UAI. Mahasiswa dengan skor 1 adalah mereka yang pendidikan terakhirnya sebelum masuk UAI adalah SMU atau SMA. Selanjutnya mahasiswa dengan skor 2, 3, dan 4 adalah mereka yang pendidikan terakhirnya sebelum masuk UAI masing-masing adalah SMK, MA, dan Pesantren.

Tabel 1d menyajikan persebaran pendapatan orang tua mahasiswa berdasarkan sumber pendanaan kuliah mereka pada tahun pertama di UAI. Mahasiswa dengan skor 1 adalah mereka yang

Tabel 1d. Descriptive statistic pendapatan bulanan orang tua mahasiswa prodi Arab UAI menurut status beasiswa.

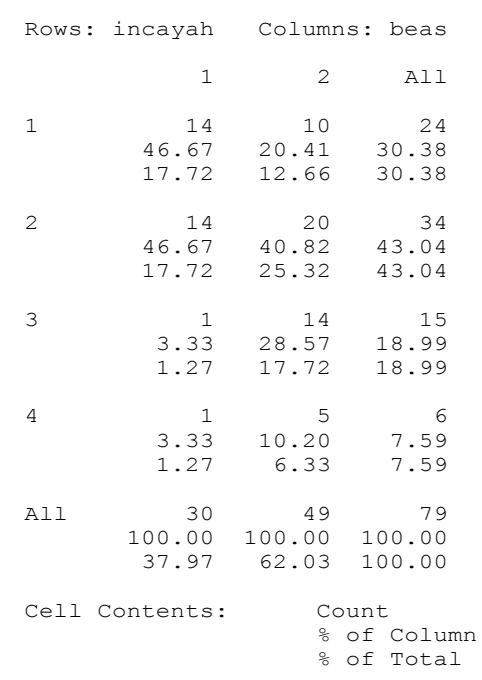

mengandalkan beasiswa, baik yang berasal dari UAI maupun dari luar UAI, untuk mendanai biaya kuliah mereka selama tahun pertama. Mahasiswa dengan skor 2 adalah mereka yang tidak mengandalkan dana beasiswa untuk mendanai biaya kuliah mereka selama tahun pertama di UAI.

Dari 79 mahasiswa sastra Arab UAI yang dijaring sebagai sampel, sekitar 62 persen dari mereka, tidak menggunakan dana beasiswa untuk mendanai biaya kuliah mereka selama tahun pertama di UAI, sedangkan sekitar 38 persen, mengandalkan dana beasiswa untuk mendanai biaya kuliah mereka selama tahun pertama.

\subsection{Indeks Prestasi Kumulatif dan Pendapatan Orang}

Tabel 2a menyajikan statistika deskriptif indeks prestasi kumulatif (IPK) pada tahun pertama perkuliahan, dari 79 mahasiswa yang dijadikan sampel. Rata-rata IPK mahasiswa dari empat angkatan adalah 3,15 dengan simpangan baku 0,68 . IPK terkecil adalah 0,69 dan IPK terbesar adalah 4,00. Median IPK mahasiswa adalah 3,33. Hasil ini mengindikasikan bahwa IPK mahasiswa terkonsentrasi di dekat IPK rata-rata dan di bawah IPK rata-rata. Indikasi ini juga diperkuat dengan 
histogram dari IPK tahun pertama, yang disajikan pada Gambar 1. Histrogram IPK menunjukkan bahwa distribusi IPK tidak normal, namun lebih menyerupai distribusi yang skewed ke kiri. Indikasi left-skewed untuk distribusi IPK juga ditunjukkan oleh skewness IPK yang negatif (1,23).

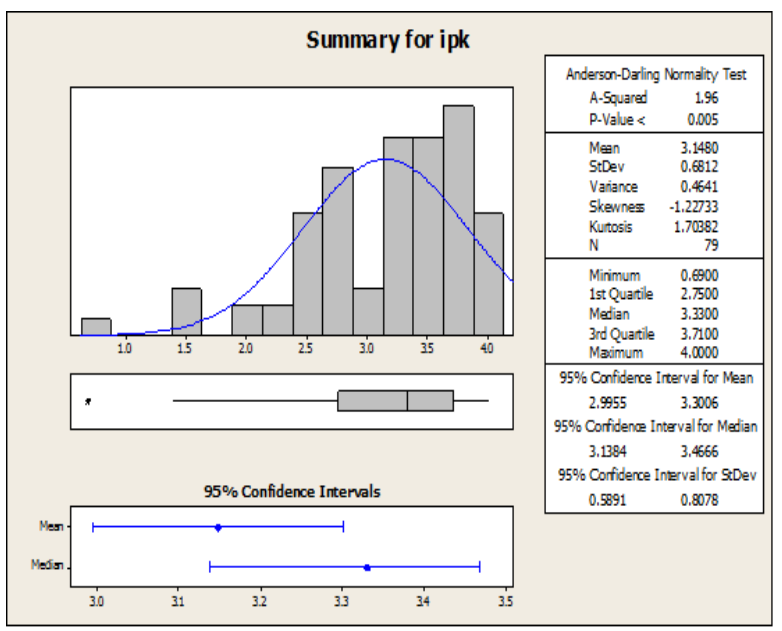

Gambar 1. Histogram IPK mahasiswa sastra arab pada tahun pertama perkuliahan

\section{Tabel 2a. Statistik desrkriptif IPK mahasiswa pada tahun pertama \\ Variable Mean StDev Minimum Median Maximum ipk $\quad 3.1480 \quad 0.6812 \quad 0.6900 \quad 3.3300 \quad 4.0000$}

Selanjutnya bila kita pilah IPK tahun pertama menurut tahun masuk mahasiswa (lihat tabel $2 b$ ), berdasarkan ukuran rata-rata IPK, dapat dikatakan bahwa kemampuan akademik mahasiswa sastra Arab masih dalam taraf normal. Pada masingmasing angkatan, IPK rata-rata mahasiswa berada di kisaran 3,00 sampai 3,30. Angkatan 2008 dan 2009 memiliki IPK rata-rata yang lebih tinggi dibandingkan IPK rata-rata angkatan 2010 dan 2011. Namun, secara umum dapat dikatakan bahwa kemampuan akademik mahasiswa dari setiap angkatan relatif berimbang. Hasil ini juga mengindikasikan bahwa rata-rata IPK sampel, tidak disebabkan oleh sebaran IPK di salah satu angkatan. Ini karena rata-rata IPK dari sampel tidak jauh berbeda dengan rata-rata IPK pada masing-masing angkatan.

Bila kita pilah IPK tahun pertama berdasarkan pendapat orang tua, baik ketika mahasiswa dengan IPK kurang dari 1,00 masih dilibatkan (tabel 2c) maupun sudah tidak dilibatkan (tabel 2d), pola rata-rata IPK tahun pertama mahasiswa tidak jauh berbeda.

Mahasiswa dengan pendapatan orang tua di bawah 2 juta rupiah perbulan memiliki rata-rata IPK paling tinggi diantara mahasiswa yang lain. Pada pendapatan orang tua yang lebih tinggi, rata-rata

\section{Tabel 2b. Statistik desrkriptif IPK tahun pertama} menurut tahun masuk

$\begin{array}{llrrrrr}\text { Variable } & \text { tmasuk } & \text { Mean } & \text { StDev } & \text { Minimum } & \text { Median } & \text { Maximum } \\ \text { ipk } & 2008 & 3.300 & 0.579 & 1.390 & 3.470 & 3.910 \\ & 2009 & 3.201 & 0.618 & 1.990 & 3.220 & 4.000 \\ & 2010 & 3.028 & 0.729 & 0.690 & 3.225 & 3.890 \\ & 2011 & 3.053 & 0.799 & 1.410 & 3.330 & 3.945\end{array}$

\section{Tabel 2c. Statistik desrkriptif IPK tahun pertama menurut pendapatan orang tua}

$\begin{array}{lllrrrr}\text { Variable } & \text { income } & \text { Mean } & \text { StDev } & \text { Minimum } & \text { Median } & \text { Maximum } \\ \text { ipk } & 1 & 3.427 & 0.586 & 1.410 & 3.555 & 4.000 \\ & 2 & 3.074 & 0.691 & 1.390 & 3.270 & 3.950 \\ & 3 & 2.845 & 0.748 & 0.690 & 2.865 & 3.730 \\ & 4 & 3.212 & 0.492 & 2.550 & 3.225 & 3.825\end{array}$

Tabel 2d. Statistik desrkriptif IPK tahun pertama menurut pendapatan orang tua, setelah mengeluarkan outlier

$\begin{array}{llrrrrr}\text { Variable incayah } & \text { Mean } & \text { StDev } & \text { Minimum } & \text { Median } & \text { Maximum } \\ \text { ipk } & 1 & 3.427 & 0.586 & 1.410 & 3.555 & 4.000 \\ & 2 & 3.074 & 0.691 & 1.390 & 3.270 & 3.950 \\ & 3 & 2.999 & 0.469 & 1.990 & 3.010 & 3.730 \\ & 4 & 3.212 & 0.492 & 2.550 & 3.225 & 3.825\end{array}$

IPK mahasiswa pada tahun pertama perkuliahan, cenderung lebih rendah. Namun, ini hanya berlaku hingga pendapatan antara 5 juta sampai kurang dari 10 juta rupiah perbulan. Mahasiswa dengan pendapatan orang tua 10 juta rupiah perbulan atau lebih (berpendapatan tinggi), justru memiliki ratarata IPK tahun pertama, lebih tinggi dibandingkan mahasiswa yang pendapatan orang tuanya antara 2 dan 5 juta rupiah perbulan, dan juga dengan mereka yang orangtuanya berpendapatan 5 juta hingga sebelum 10 juta rupiah perbulan. Namun, rata-rata IPK mahasiswa dengan pendapatan orang tua 10 juta rupiah perbulan atau lebih, masih lebih rendah dibandingkan mahasiswa yang pendapatan orang tuanya di bawah 2 juta rupiah perbulan (atau berpendapatan rendah).

Secara kasar dapat dikatakan bahwa terdapat hubungan terbalik antara prestasi akademik 
mahasiswa pada tahun pertama dan tingkat pendapatan orang tua.

Tabel 3. Hasil uji ANOVA perbedaan rata-rata IPK menurut tingkat pendapatan orang tua

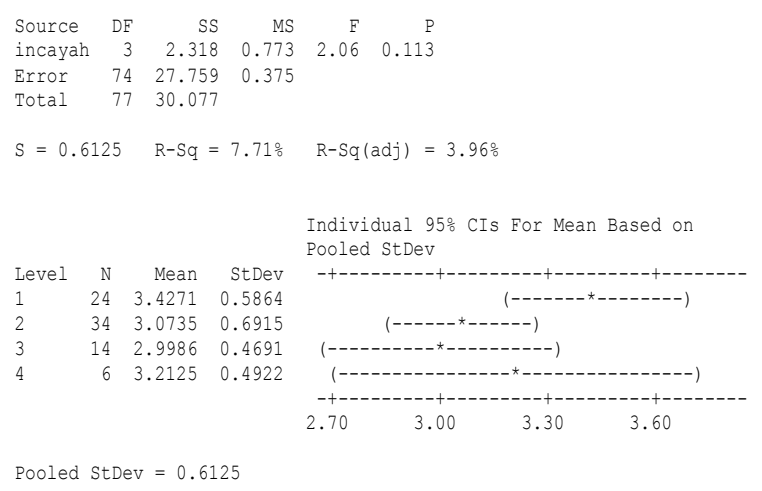

Tabel 4. Hasil uji ANOVA perbedaan rata-rata IPK menurut tingkat pendapatan orang tua dan tahun masuk

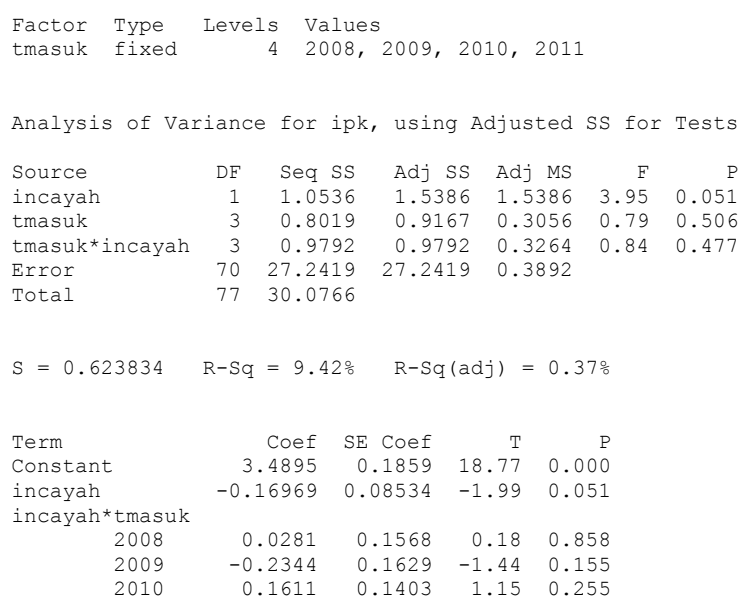

Prestasi akademik mahaiswa umumnya lebih rendah, untuk tingkat pendapatan orang tua yang lebih tinggi. Namun hubungan ini hanya berlaku

hingga tingkat pendapatan orang tua sebesar 10 juta rupiah. Untuk mahasiswa dengan tingkat pendapatan orang tua di atas 10 juta rupiah, hubungan ini tidak berlaku.

Untuk memperoleh dukungan empirik terhadap konklusi di atas, dilakukan pengujian beda ratarata terhadap rata-rata IPK tahun pertama dari berbagai status ekonomi keluarga mahasiswa. Pengujian yang digunakan adalah uji analysis of variance (ANOVA) satu arah. Digunakan statistik uji $\mathrm{F}$ pada taraf kemaknawian 5\%. Hasil pengujian disajikan di tabel 3.
Hasil uji ANOVA di tabel 3 ternyata tidak siginfikan pada taraf kemaknawian 5\%. Ini berarti bahwa hipotesa nol yang menyatakan tidak

Tabel 5. Hasil uji ANOVA perbedaan rata-rata IPK menurut tingkat pendapatan orang tua dan jenis kelamin mahasiswa

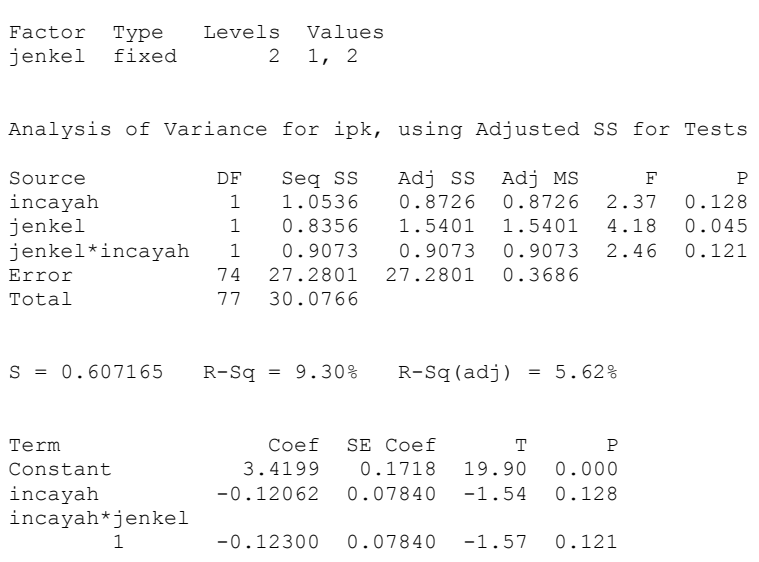

terdapat perbedaan dalam rata-rata IPK tahun pertama antara satu mahasiswa dengan mahasiswa yang lain, yang berasal dari status ekonomi keluarga (yang dilihat dari pendapatan perbulan orang tua) yang berbeda, tidak dapat ditolak.

\subsection{Indeks Prestasi Kumulatif, Pendapatan Orang Tua dan Tahun Masuk}

Tabel 4 menjelaskan hasil pengujian perbedaan rata-rata IPK tahun pertama, menurut pendapatan orang tua mahasiswa, setelah mempertimbangkan tahun masuk mereka ke UAI.

Tahun masuk secara individual tidak mampu menerangkan perbedaan prestasi akademik mahasiswa sastra Arab UAI secara bermakna pada taraf nyata 5\%. Ini artinya, tanpa melihat latar belakang ekonomi keluarga, tidak ditemukan perbedaan yang bermakna antara kemampuan atau prestasi akademik siswa yang tahun masuknya berbeda.

Adapun hasil pengujian efek interaksi tahun masuk dan pendapatan orang tua, memperlihatkan bahwa setelah mempertimbangkan tahun masuk ke UAI, pendapatan orang tua belum juga mampu menerangkan perbedaaan kemampuan akademik mahasiswa selama tahun pertama perkuliahan mereka

\subsection{Indeks Prestasi Kumulatif, Pendapatan Orang Tua dan Jenis Kelamin}

Tabel 5 menjelaskan hasil pengujian perbedaan rata-rata IPK tahun pertama, menurut pendapatan 
orang tua mahasiswa, setelah mempertimbangkan jenis kelamin mereka.

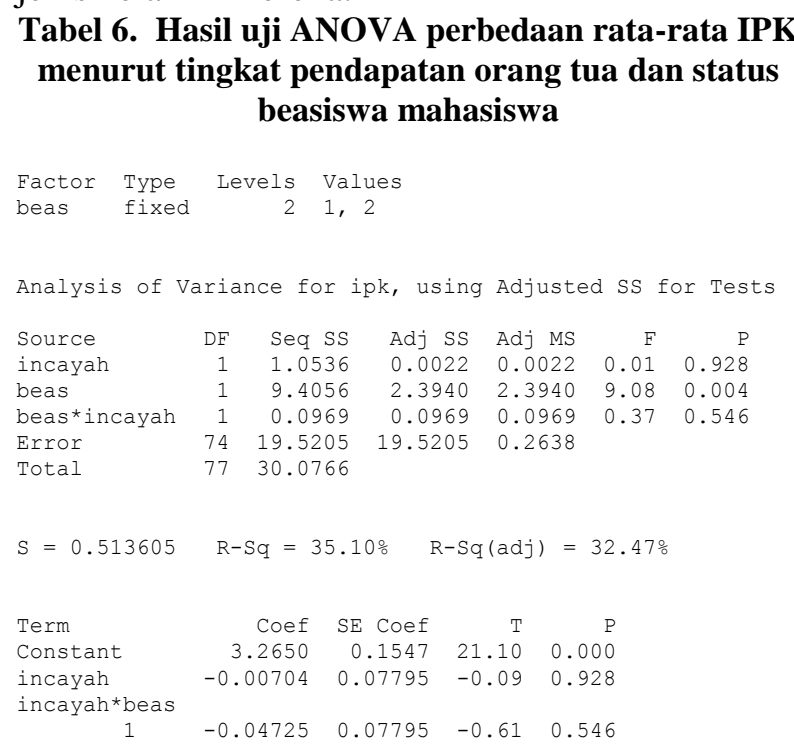

Jenis kelamin secara individual mampu menerangkan keragaman prestasi akademik mahasiswa sastra arab UAI secara bermakna pada taraf nyata 5\%. Hasil pengujian efek interaksi jenis kelamin dan pendapatan orang tua memperlihatkan bahwa setelah mempertimbangkan jenis kelamin, pendapatan orang tua belum mampu menerangkan perbedaaan kemampuan akademik mahasiswa selama tahun pertama perkuliahan mereka. P-value dari efek interaksi pendapatan orang tua dengan dummy variable indikator jenis kelamin mahasiswa (apakah ia perempuan atau laki-laki), masing-masing nilainya jauh di atas taraf nyata $5 \%$.

\subsection{Indeks Prestasi Kumulatif, Pendapatan Orang Tua dan Status Beasiswa}

Tabel 6 menjelaskan hasil pengujian perbedaan rata-rata IPK tahun pertama, menurut pendapatan orang tua mahasiswa, setelah mempertimbangkan status beasiswa mereka.

Status beasiswa secara individual mampu menerangkan keragaman prestasi akademik mahasiswa sastra arab UAI secara sangat bermakna ( $\mathrm{p}$-valuenya $=0,004$ ) pada taraf nyata $5 \%$. Namun, hasil pengujian efek interaksi status beasiswa dan pendapatan orang tua memperlihatkan bahwa setelah mempertimbangkan status beasiswa, pendapatan orang tua belum mampu menerangkan perbedaaan kemampuan akademik mahasiswa selama tahun pertama perkuliahan mereka.

Tabel 7. Hasil uji ANOVA perbedaan rata-rata IPK menurut tingkat pendapatan orang tua dan latar pendidikan pra-universitas mahasiswa

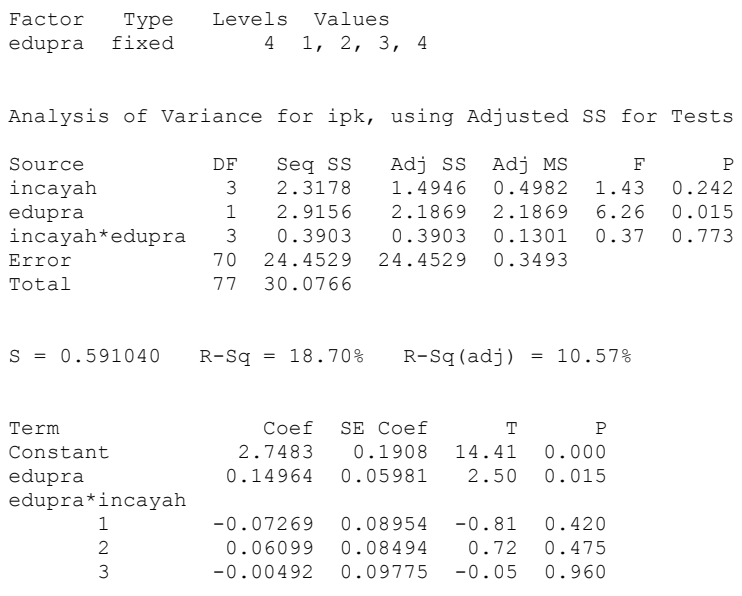

\subsection{Indeks Prestasi Kumulatif, Pendapatan Orang Tua dan Latar Belakang Pendidikan Pra-Universitas}

Tabel 7 menjelaskan hasil pengujian perbedaan rata-rata IPK tahun pertama, menurut pendapatan orang tua mahasiswa, setelah mempertimbangkan latar pendidikan pra-universitas mereka.

Latar pendidikan pra-universitas secara individual mampu menerangkan keragaman prestasi akademik mahasiswa sastra Arab UAI secara sangat bermakna ( $p$-valuenya $=0,015)$ pada taraf nyata $5 \%$. Sementara hasil pengujian efek interaksi latar pendidikan pra-universitas dan pendapatan orang tua memperlihatkan bahwa setelah mempertimbangkan latar pendidikan prauniversitas, pendapatan orang tua masih juga belum mampu menerangkan perbedaaan kemampuan akademik mahasiswa selama tahun pertama perkuliahan mereka.

\section{KESIMPULAN}

Apabila ditelusuri satu per satu, berdasarkan indikator kelompok pendapatan orang tua, diperoleh penjelasan bahwa indikator mahasiswa berasal dari keluarga dengan pendapatan orang tua 2 juta rupiah per bulan atau kurang, dapat menerangkan rata-rata IPK mahasiswa pada tahun pertama perkuliahan secara signifikan. Ini 
menunjukkan bahwa model mampu membedakan kemampuan akademik mahasiswa yang pendapatannya orang tuanya 2 juta rupiah perbulan atau kurang dan yang di atas 2 juta rupiah perbulan. Rata-rata mahasiswa yang berasal dari keluarga dengan pendapatan orang tua 2 juta rupiah perbulan atau kurang, diduga memiliki prestasi akademik lebih tinggi 0,35 poin dibandingkan mahasiswa dengan pendapatan orang tua di atas 2 juta rupiah perbulan.

Hasil pengujian selanjutnya mengindikasikan bahwa perbedaan prestasi akademik mahasiswa menurut kelompok pendapatan orang tua, tidak bisa terlihat secara nyata, pada masing-masing tahun masuk atau angkatan di UAI. Hal yang sama juga ditemukan bila kita analisa perbedaan prestasi akademik mahasiswa menurut kelompok pendapatan orang tua, pada masing-masing kelompok jenis kelamin, status beasiswa, dan pendidikan terakhir sebelum memasuki UAI. Namun, hasil pengujian mengindikasikan bahwa perbedaan prestasi akademik mahasiswa dapat teramati secara signifikan (nyata) bila didasarkan pada perbedaan jenis kelamin, apakah mereka menerima beasiswa atau tidak, dan perbedaan dalam pendidikan terakhir mereka sebelum masuk di UAI.

\section{DAFTAR PUSTAKA}

[1] A.C. Cameron and P.K. Trivedi. Microeconometrics: Methods and Applications. Cambridge University Press, 2005.

[2] Child Trends and Center for Child Health Research. Early Child Development in Social Context. New York, 2004.

[3] Dahl and L. Lochner. The Impact of Family Income on Child Achievement: Evidence from the Earned Income Tax Credit. NBER Working Paper, 1999.

[4] R. Haveman and B. Wolfe. The Determinants of Children's Attainments: A Review of Methods and Findings. Journal of Economic Literature, 33(4):1829\{1878, Dec. 1995.

[5] D. Levy and G. Duncan. Using Sibling Samples to Assess the Effect of Childhood Family Income on Completed Schooling. Working Paper, 1999.

[6] S. Mayer. What Money Can't Buy: Family Income and Children's Life Chances. Harvard University Press, Cambridge, 1997. 